\title{
Evaluating Morphometric Parameters of Haro River Drainage Basin in Northern Pakistan
}

\author{
Muhammad Sanaullah" ${ }^{1 *}$, Iftikhar Ahmad², Muhammad Arslan³ \\ Sajid Rashid Ahmad², Muhammad Zeeshan ${ }^{1}$
}

${ }^{1}$ Institute of Geology, University of the Punjab, Lahore, Pakistan

${ }^{2}$ College of Earth and Environmental Sciences, University of the Punjab, Lahore, Pakistan ${ }^{3}$ Geosciences Department, King Fahd University of Petroleum and Minerals, Dhahran, Saudi Arabia

Received: 27 August 2016

Accepted: 11 January 2017

\begin{abstract}
We evaluated morphometric parameters of the Haro River drainage network to determine flooding potential in the river basin. The drainage network is derived from topographic maps while using shuttle radar topography mission digital elevation model (SRTM-DEM) and geographic information systems (GIS). A total of 2917 streams (dendritic to semi-dendritic) are recognized, among which 1,536 are identified as first-order streams, followed by 731 as second order, 360 as third order, 173 as fourth order, 78 as fifth order, and 39 as sixth order. Linear and areal morphometric parameters revealed lower values for form factor (0.25), stream frequency (0.99), and drainage density $(0.84 \mathrm{~km} / \mathrm{sq} . \mathrm{km})$, which suggest that the basin is being elongated with permeable strata; whereas lower values of mean bifurcation ratio (2.0) and relief ratio (20.68) indicate less potential for flooding in the main river channel. Understanding drainage morphometry could bring better hydrological solutions for similar studies.
\end{abstract}

Keywords: morphometry, drainage basin, stream order, DEM (digital elevation model), Haro River

\section{Introduction}

A drainage basin is a fundamental unit of fluvial landscape whose morphometric properties govern the flow of surface water in a network of rivers and streams [1]. Understanding morphometric properties of a drainage basin has been considered a primary tool for agriculture and sustainable watershed planning [2]. Nevertheless, a quantitative description of these properties - especially drainage texture, pattern distribution, shape parameters,

*e-mail: sana.ullah.geo@pu.edu.pk and relief characteristics - requires a detailed description of the topographic and geomorphological features [3-4]. Earlier studies employed these characteristics to describe a variety of geomorphic processes such as sediment yields assessment, erosion rates estimation, water resources management, and flood peaks prediction [5-6]. Nevertheless, assessing morphometric parameters requires analysis on drainage parameters, i.e., length of drainage channels, ordering of streams, basin area and perimeter measurements, stream frequency, drainage density, bifurcation ratio, basin relief, ruggedness number, texture ratio, time of concentration, etc. [7]. 
Several methods have been used to identify the drainage networks, namely conventional field observation procedures, development of topographic maps, employing tools of remote sensing, and/or applying shuttle radar topography mission digital elevation models (SRTMDEM) [8-9]. Examining drainage networks by field observations has certain limitations; for instance, firsthand analysis and rough terrain throughout the network or at least for vast areas. On the other hand, fluvial channels represented by blue lines on topographic maps also have certain limitations as they are biased in representation of real drainage networks due to cartographic generalizations and/or subjective judgments [1]. Moreover, cartographical representations often ignore valleys as fluvial channels, despite the fact that they play a potential role in collecting and transportating surface water flow. It is for these reasons that Horton proposed the inclusion of first-order stream drainage network studies. In later years, Shreve and Tarboton suggested the inclusion of exterior links that further helped to improve cartographical representation [1,10]. Nevertheless, in recent years the development of SRTM-DEM has resolved these problems as it can employ all of the aforementioned features in a single platform while comprehensively extracting the drainage networks.

In this study, the drainage network of the Haro River basin is extracted from the following sources: 1) topographic maps and 2) SRTM-DEM, in which blue 1 ines represent drainage networks while the part extracted from the SRTM-DEM represents exterior links alongside the blue lines. Evaluating the Haro's river drainage network morphometric parameters is a pioneer study in the region, which aims to provide hydrologic importance in the region compared to the flooding potential in the main channel.

\section{Study Area}

The Haro River Basin is a hydrological unit of the Potwar Plateau, whose height extends up to 1,500 feet with a length of $18,129 \mathrm{~km}^{2}$, demarcating a clear physiographic region of Pakistan. Geologically, the plateau is a part of Nimandric Basin, which is also a fragment of the Himalaya Range, while the Kala Chitta hills define the lower boundary of the Haro Basin. These hills are composed of Triassic to Eocene formations [11]. Geographically, the study area lies between $33.99972 \mathrm{~N}$ and $72.20555 \mathrm{E}$ to $34.0580556 \mathrm{~N}$ and $73.42722 \mathrm{E}$ (Fig. 1). The basin has a catchment area of 3,100.55 km², in which the $120 \mathrm{~km}$ long Haro flows through different geological formations contrasting geomorphological features with tightly folded anticlines and synclines. The river originates from Nathia Gali (34.06667 N and 73.38334 E) and Changla Gali (34.00000 N and 73.383333 E), which merge near Dotara to form the Stora Haro; while Lora Haro from the hills of Murree joins Stora Haro near Jabri. The Haro in the upper basin is majorly fed by the following tributaries: 1) Nilan Kas, which drains northwest and joins Haro near Khanpur; 2) Lora Haro from Murree hills; and 3) Stora Haro from the mountains of Nathia Gali. However, minor contributions are attributed to the Jabbi Kas, Jhablat Kas, Nandna Kas, and Shakardara Kas tributaries. The Haro flows through narrow and deep gorges whose valley is ' $\mathrm{V}$ '-shaped in most places until it reaches the Khanpur area. The climate of the region is strongly influenced by precipitation and temperature, and longterm changes prevail in these two elements to define the climate pattern.

\section{Methodology}

Morphometric parameters of the drainage networks such as stream order, stream length, bifurcation ratio, basin relief, relief ratio, elongation ratio, drainage density, length of overland flow, circulatory ratio, flow direction, and stream frequency were evaluated with well-established equations. The drainage network was developed from

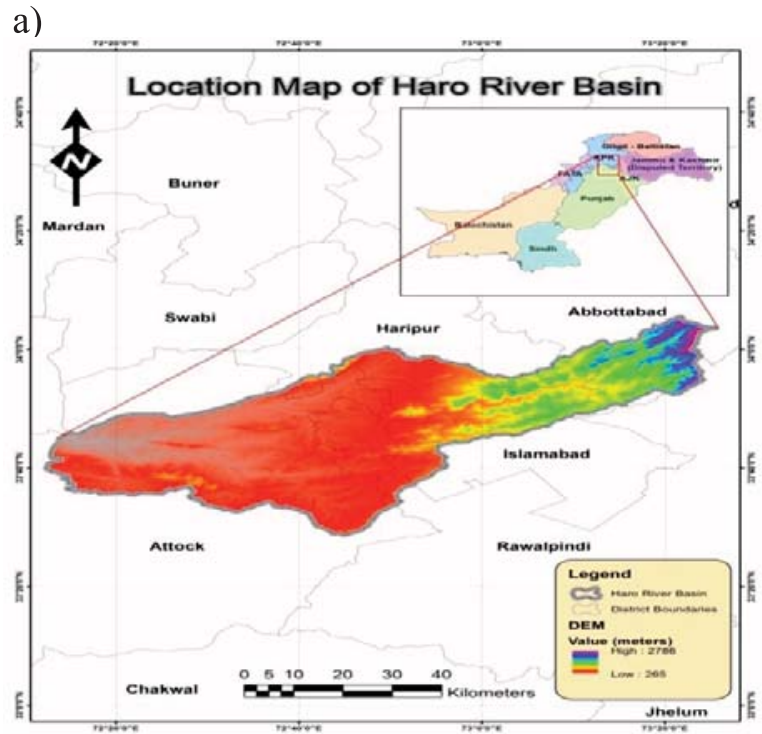

b)

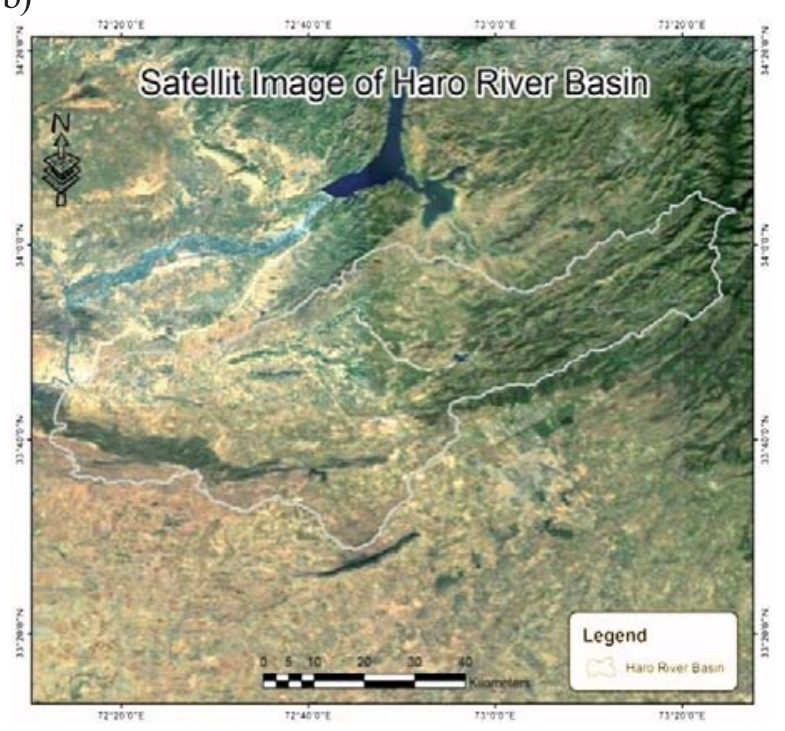

Fig. 1. Location map a) and satellite image b) of the study area. 


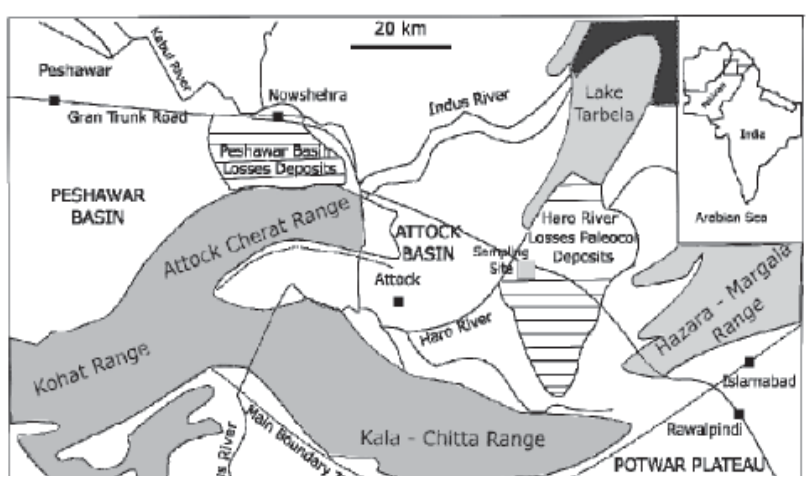

Fig. 2. Map showing geological identities of the study area.

topographic sheets, i.e., $43 \mathrm{C}$ and $43 \mathrm{G}$ at the scale of $1: 250,000$ and $43 \mathrm{G} / 1,43 \mathrm{G} / 5$ and $43 \mathrm{~F} / 8$ at the scale of 1:50,000. The sheets were obtained from a geological survey of Pakistan and processed in a GIS environment for digitizing, while an online repository of SRTM was considered a database tool. The catchment area of the Haro was extracted and cross-referenced with a boundary of the basin in DEM. The DEM precision of the extracted drainage networks was set to 90-m resolution as quality features of the basin. The DEM-associated errors such as peaks and sinks were deleted to minimize discontinuities. The filled DEM approach, also known as eight-direction pour point model, was used to calculate the flow direction for each pixel in which flow of the water at each pixel is influenced by one of the eight surrounding pixels [12-13]. The extraction of drainage network was performed using a raster calculator along with contour crenulation [14].

An ArcGIS hydrology toolset was applied to extract and calculate the linear and areal parameters of the drainage basin (described previously). The parameters for stream order, stream lengths, and stream numbers were measured as described by following Strahler and Horton laws [15]. The geological map of Pakistan - and particularly the Kala Chitta Range - are used as reference maps [16].
Table 2. Bifurcation ratio for the drainage basin.

\begin{tabular}{|c|c|}
\hline Bifurcation & \\
\hline Bifurcation ratio first order/second order & 2.1 \\
\hline Bifurcation ratio second order/third order & 2.0 \\
\hline Bifurcation ratio third order/fourth order & 2.0 \\
\hline Bifurcation ratio fourth order/fifth order & 2.2 \\
\hline Bifurcation ratio fifth order/sixth order & 2.2 \\
\hline Mean bifurcation ratio & $\mathbf{2 . 0}$ \\
\hline
\end{tabular}

\section{Results and Discussion}

The morphometric parameters of the Haro drainage networks are presented in Tables 1 and 2. The specific description on general drainage basin parameters is described in the following sections.

\section{Stream Order}

Stream order analysis illustrates the presence of first- to sixth-order streams throughout the drainage pattern of the Haro (Fig. 3b). In total, 2917 streams are identified, among which 1,536 streams are designated as first order, 731 as second order, 360 as third order, 173 as fourth order, 78 as fifth order, and 39 as sixth order (Fig. 4c, Table 1). The first- and second-order streams of Nathia Gali merge together and form a fourthorder stream called Stora Haro; similarly, streams in Murree and Changla Gali produce another fourth-order stream known as Lora Haro. Both Lora Haro and Stora Haro merge at Jabri to result in the formation of a fifthorder Haro River. Afterward, Nilan Kas, a third-order stream, falls into the Haro in the Khanpur Dam area, rendering it stronger in flow potential. Among four major tributaries, Nandna Kas is observed to be a fifth-order stream, followed by Shkardara Kas, a fourth-order stream. Nandna Kas is the longest stream of all, which is fed by mountains of Kala Chitta; whereas Shakardara Kas is a fourth-order stream that merges with the Haro at the far end (i.e., 33.73972 N, 72.295278 E). Downstream from Khanpur Dam (near Sultanpur), the Haro makes a major

Table 1. Morphometric parameters of the Haro River drainage network derived from DEM.

\begin{tabular}{|c|c|c|c|c|c|}
\hline Stream Order $(\mathrm{u})$ & Stream Number $(\mathrm{Nu})$ & Log Nu & Stream Length $(\mathrm{Lu})$ & Log Lu & Lsm \\
\hline 1 & 1,536 & 3.19 & 1,260 & 3.1 & 0.82 \\
\hline 2 & 731 & 2.86 & 680 & 2.83 & 0.93 \\
\hline 3 & 360 & 2.56 & 340 & 2.53 & 0.94 \\
\hline 4 & 173 & 2.24 & 180 & 2.25 & 1.04 \\
\hline 5 & 78 & 1.89 & 103 & 2.01 & 1.32 \\
\hline 6 & 39 & 1.59 & 54 & 1.73 & 1.38 \\
\hline
\end{tabular}



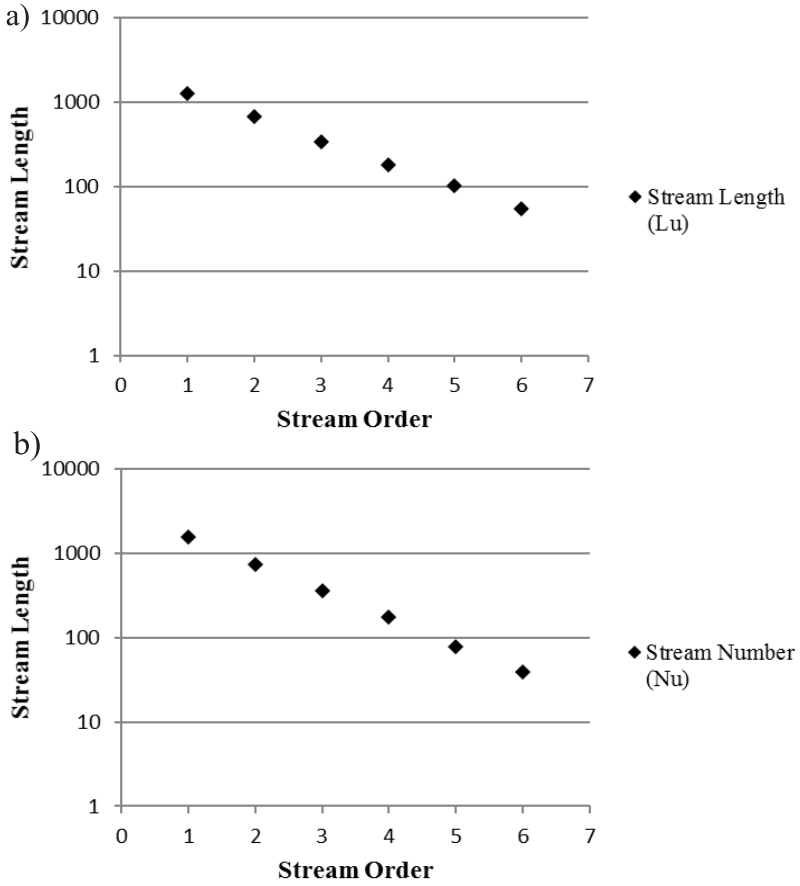

Fig. 3. Graphs showing the relationship of stream order with stream length a) and stream number b) of the study area.

diversion at Gandghar Range, resulting in a drainage divide between the Haro and Dor rivers [17]. This drainage divide has been previously reported as a function of local tectonics and the rock-type features [18]. Moreover, a series of thrusts has been previously observed upstream in the Haro as well [19].

Parallel to the Gandghar Range divide, a fourth-order stream, namely Jabbi Kas, joins the Haro (33.89639 N and $72.74583 \mathrm{E}$ ). Nevertheless, flow accumulation other than the main Haro is majorly attributed to the fifth-order stream Nandna Kas (Figs 1a and 3b). The Haro Basin drainage pattern is dendritic to sub-dendritic, which indicates the presence of structural controls [20]. Some areas of the basin exhibit a parallel drainage pattern and are of uniform slopes with low-resistant strata in the channel bed. Nevertheless, the stream network is not purely dendritic due to the heterogeneity in the texture of the rocks exposed. This could be due to the fact that the properties of the network play a key role in landform-making processes [2]. Keeping aside these facts, the Haro rises from the zone of thrusts, varying its traverse in accordance to geological and structural controls. The river originates along the Nathia Gali Fault (NGF) and follows the other thrusts in Attock [19]. Regression analysis further confirms a strong inverse relationship between stream order and stream length (Fig. 3a), as well as stream order (Fig. 3b), i.e., $84 \%$ and $81 \%$, respectively.

\section{Stream Length}

Stream length evaluations for different orders of streams showed significant variations, i.e., ranging from 54 to $1,260 \mathrm{~km}$. The length of first-order streams is observed to be $1,260 \mathrm{~km}$, second-order $680 \mathrm{~km}$, third-order $340 \mathrm{~km}$, fourth-order $180 \mathrm{~km}$, fifth-order $103 \mathrm{~km}$, and sixth-order 54 km (Figs 3(a-b), Table 1). Nevertheless, streams of the smaller order are found at high altitude compared to the streams of higher order [21]. This is the reason that Nandna Kas is found at the lowermost altitude. Furthermore, streams at low elevation possess long channels with high flow accumulation density compared to the smaller streams. The total length of the stream network is observed to be 2,617 km (Table 1).

\section{Bifurcation Ratio}

The bifurcation ratios for different order streams are presented in Table 2. It has been well established that the bifurcation ratio ranging between 3.0 and 5.0 indicates the least influence of geological features on the drainage network [22]. However, results obtained of mean bifurcation ratio for the Haro are contradictory, i.e., mean of 2.0; and hence reveal the significant influence of geological structures on the drainage network [1, 23]. Moreover, the observed value shows a structural control for the basins with undisturbed geological structures [2].

\section{Basin Relief}

The measurement of basin slope and/or basin relief is a well-established hydrologic parameter [24]. The steeper hillslopes, increasing relief, and high stream gradients reveal increasing chances of flood peaks and sediment transportation [25]. Basin relief for the Haro Basin is observed to be $2,521 \mathrm{~m}$, which reflects the slope being a moderate-to-high gradient basin. In context of the observed value, flash floods are least expected in the studied area; nevertheless, the Haro faces moderate variations in relief as it passes through different geological identities of Hazara and the Kala Chitta Range [26] (Fig. 3c).

\section{Relief Ratio}

A relief ratio of $\sim 20.7$ for the Haro Basin indicates the presence of low-resistance rocks in the study area [25, 27]. This dimension allows for an assessment of relative relief in a basin independent of scale or topography difference. The ratio further measures an overall gradient of a drainage basin while indicating the intensity of erosion. The relief ratio for the studied area is an indicator of low relief drainage basin morphology; nevertheless, the Haro Basin has great diversity in relief from Nathia Gali to the Attock area (Fig. 3d).

\section{Elongation Ratio}

An elongation ratio of 0.75 for the studied area represents the basin as a low relief area as the elongation 
ratio values of 1.0 typically denotes the regions with low relief [27-28]. It further helps us understand the shape of a drainage basin along with its hydrological character [2].

\section{Drainage Density}

Drainage density represents landscape dissection, land infiltration capacity, runoff potential, vegetation cover, and general climate of the basin [29]. Drainage density, on one hand, is a tool to elucidate interacting factors responsible for surface runoff, while on the other hand it can influence the output of sediments and water in the drainage basin. The Haro Basin has a drainage density of 0.84 , which provides a numerical measurement of its runoff potential along with the outcrop dissection and closeness of the streams [6]. The low value of drainage density further reveals high infiltration capacity of the strata in the region (Fig. 4). Besides, it is found that in fluvial systems that are underlain by less soluble rocks, their bedrock geology affects basin hydrology [22]. This parameter shows the closeness of the spacing channels as a quantitative measure for the basin. Lastly, the drainage density of the Haro Basin favors vegetation cover throughout the region [2].

\section{Length of Overland Flow}

This parameter is useful when studying terrain development as it affects morphological changes [27]. The length of overland flow for the Haro drainage basin is observed to be 2.38, which indicates a low rate of runoff in the basin. Nevertheless, it shows a strong relationship with channel conservation as the shorter length of overland flow will increase the speed of runoff that drains into the stream.

\section{Circulatory Ratio}

The circulatory ratio is influenced by geological structures, climate of the area, relief of the basin, and length of streams [6]. Moreover, it relates the ratio of the basin area to the circular area of the same circumference. The circulatory ratio of 0.31 for the Haro shows that the basin is elongated in shape. Christopher et al. [2] described a circulatory ratio range (i.e., 0.4 to 0.5 ) for elongated and permeable homogeneous material. There is a reverse relationship between circulatory ratio and the circulatory of the basin. For these reasons, the basin is observed to be elongated in shape with high permeability.
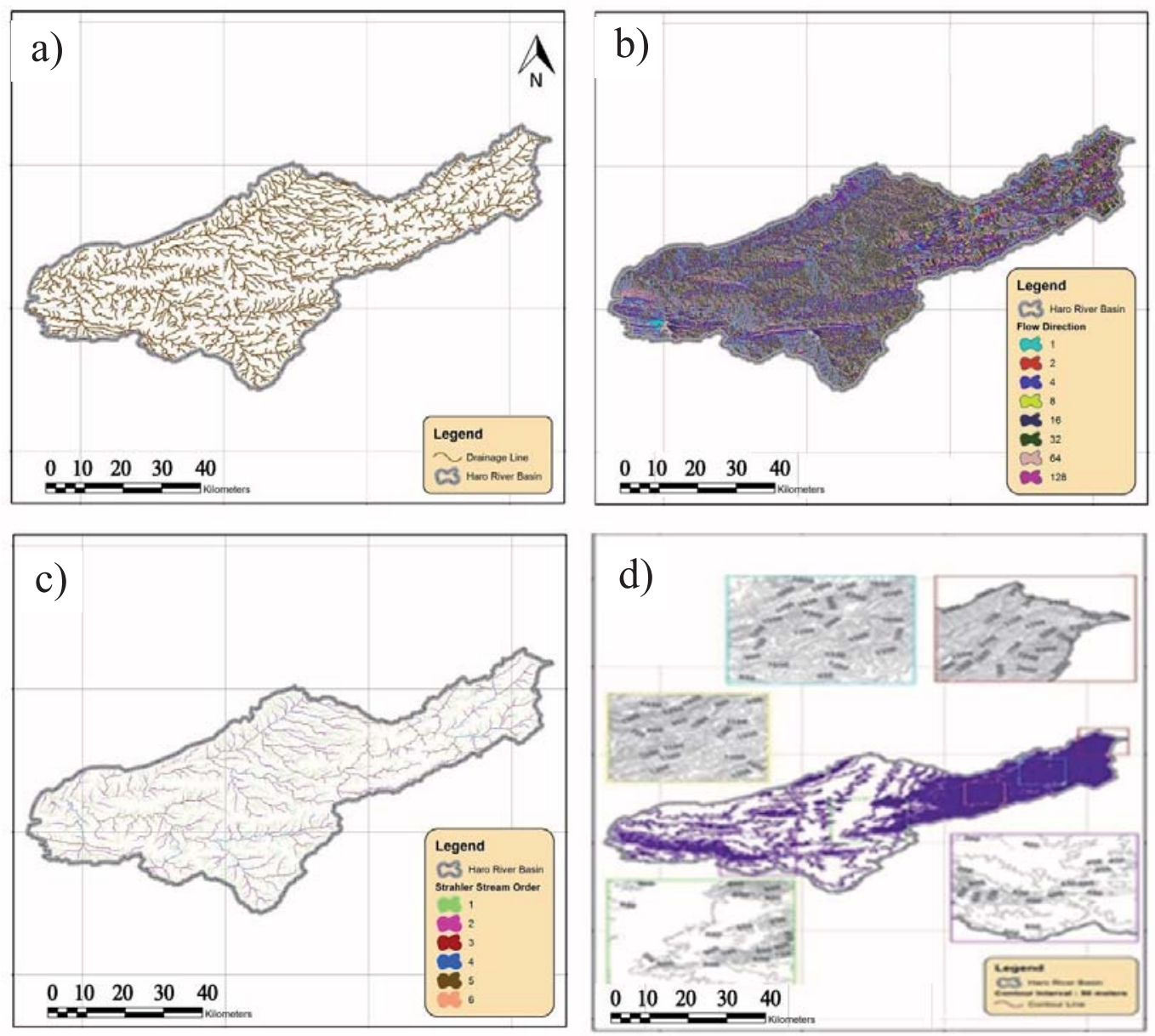

Fig. 4. Maps of the stream order a), drainage pattern b), contour c), and flow direction d). 


\section{Flow Direction and Stream Frequency}

The dominant flow direction map for the Haro Basin shows the flow dominancy southwest to west (Fig. 4d). More precisely, downstream of Khanpur Dam, the river flows northwest up to the Gandghar Range divide, while Jabbi Kas enhances the flow of the river to the southwest. Stream frequency for the basin is recorded at 0.99, which reflects the basin as a permeable low-relief basin. Generally, high stream frequency is associated with sparse vegetation, high relief conditions, impermeable subsurface material, and low infiltration capacity [31].

\section{Conclusions}

In a nut shell, computed morphometric characteristics elucidate that the SRTM-derived DEM model was an effective choice toward assessing the Haro River drainage basin. The basin can be considered to be of a sixth order; although the first and the second order streams are dominant in the southeastern parts of the basin, the major tributary appears to be of the fifth order. The stream network of the basin is of dendritic to semi dendritic pattern, signifying the textural variation. Findings of the mean bifurcation ratio (2.0), stream frequencies, and the basin length suggest a low potential of flooding in the Haro, whereas drainage density and stream frequency indicate the presence of permeable subsurface lithology. Similarly, circulatory ratio (0.31), elongation ratio (0.75), and low form factor $(0.25)$ reflect the elongated nature of the basin, while parameters of relief ratio and relief factor reveal high diversity characteristics. The drainage pattern analysis of the studied area implicates a structural control that may be a likely cause of low circularity ratio. It can be concluded that the systematic analysis of morphometric parameters interpreted in a GIS environment can provide comprehensive and solutionbased information on drainage characteristics for a river basin with respect to flooding. It is further recommended to examine land use, climate, and soil type for good understanding of hydrologic processes by sub basin analysis. The resulting statistics may help in understanding land form conditions and groundwater potential of the study area.

\section{References}

1. OZDEMIR H., BIRD D. Evaluation of morphometric parameters of drainage networks derived from topographic maps and DEM in point of floods. Environmental Geology, 56, 1415, 2009.

2. CHRISTOPHER O., IDOWU A.O., OLUGBENGA, A.S., Hydrological Analysis of Onitsha North East Basin using geoinformatic techniques. World Applied Sciences Journal, 11, 1297, 2010.

3. SINGH P., GUPTA A., SINGH M. Hydrological inferences from watershed analysis for water resource management using remote sensing and GIS techniques The
Egyptian Journal of Remote Sensing and Space Science, 17, 111, 2014.

4. THOMAS J., JOSEPH S., THRIVIKRAMJI K., ABE G., KANNAN N. Morphometrical analysis of two tropical mountain river basins of contrasting environmental settings, the southern Western Ghats, India. Environmental Earth Sciences, 66, 2353, 2012.

5. BAGYARAJ M., GURUGNANAM B. Significance of morphometric studies, soil characteristics, erosion phenomena and landform processes using Remote Sensing and GIS for Kodaikanal Hills, Tamil Nadu, South India. Research Journal of Environmental and Earth, 4, 221, 2011.

6. ZENDE A.M., NAGRAJAN R. Drainage morphology approach for water resources development of sub watershed in Krishna basin. International Journal of Computer and Communication Technology, 2, 13, 2011.

7. VERSTAPPEN H. TH. A Review of: “Applied Geomorphology: Geomorphological Surveys for Environmental Development. Elsevier Science Publishers: 437, 1983.

8. MULDER V.L., DE BRUIN S., SCHAEPMAN M.E., MAYR T.R. The use of remote sensing in soil and terrain mapping - A review. Geoderma, 162 (1), 1, 2011.

9. ARSLAN M., ULLAH I., BAQIR M., SHAHID N. Evolution of flood management policies of Pakistan and causes of flooding in year 2010. Bulletin of Environmental Studies, 1 (1), 29, 2016.

10. GANGODAGAMAGE C., BELMONT P., FOUFOULAGEORGIOU E. Revisiting scaling laws in river basins: New considerations across hillslope and fluvial regimes. Water Resources Research, 47 (7), 2011.

11. WARWICK P.D. Overview of the geography, geology and structure of the Potwar regional framework assessment project study area, north-ern Pakistan. Regional Studies of the Potwar Plateau Area, northern Pakistan. US Geological Survey Bulletin, 2078, 2007.

12. PIKE R.J., EVANS I.S., HENGL T. Geomorphometry: a brief guide. Developments in Soil Science, 33, 3, 2009.

13. WILSON J.P. Digital terrain modeling. Geomorphology, 137 (1), 107, 2012.

14. YOUSSEF A.M., PRADHAN B., HASSAN A.M. Flash flood risk estimation along the St. Katherine road, southern Sinai, Egypt using GIS based morphometry and satellite imagery. Environmental Earth Sciences, 62 (3), 611, 2011.

15. RAO N.S., MOEEN S., RAO P.S., DINAKAR A., RAO P.N., SUNITHA B., SRINIVASU N. Morphometric appraoch using remote sensing and GIS in watershed management. Journal of Applied Geochemistry, 18 (1), 45, 2016.

16. GEOLOGICAL SURVEY OF PAKISTAN (GSP), Geological map of Pakistan, 2005.

17. HYLLAND M.D. Geology of the Southern Gandghar Range and Kherimar Hills, Northern Pakistan. Oregon State University (PhD Dissertation), 1990.

18. SHEHZAD F., MAHMOOD S.A., GLOAGUEN R. Drainage network and lineament analysis: an approach for Potwar Plateau (Northern Pakistan). Journal of Mountain Science, 6, 14, 2009.

19. YEATS R.S., LAWRENCE R.D. Tectonics of the Himalayan thrust belt in northern Pakistan. In Haq, B U, and Milliman, J D (eds) Marine geology and oceanography of Arabian Sea and coastal Pakistan: New York, Van Nostrand Reinhold, 39, 177, 1984.

20. TAGUE C.L., CHOATE J.S., GRANT G. Parameterizing sub-surface drainage with geology to improve modeling streamflow responses to climate in data limited environments. Hydrology and Earth System Sciences, 17, 341, 2013. 
21. NAGESWARA R.K., SWARNA L.P., ARUN K.P., KARISHNA M.H. Morphometric Analysis of Gostani River Basin in Andhra Pradesh State, India Using Spatial Information Technology. International Journal of Geomatics and Geosciences, 1, 179, 2010.

22. EZE E.B., EFIONG J. Morphometric parameters of the Calabar River basin: implication for hydrologic processes. Journal of Geography and Geology, 2 (1), 18, 2010.

23. YOUSSEF A.M., PRADHAN B., HASSAN A.M. Flash flood risk estimation along the St. Katherine road, southern Sinai, Egypt using GIS based morphometry and satellite imagery. Environmental Earth Sciences, 62 (3), 611, 2011.

24. ALTIN T.B., ALTIN B.N. Development and morphometry of drainage network in volcanic terrain, Central Anatolia, Turkey. Geomorphology, 125 (4), 485, 2011.

25. MESA L.M. Morphometric analysis of a subtropical Andean basin. Environmental Geology, 50 (8), 1235, 2006.

26. SHAH S.M.I. Stratigraphy of Pakistan. Geological Survey of Pakistan, 22, 2009.

27. MAGESH N.S., CHANDRASEKAR N., SOUNDRANAYAGAM J.P. Morphometric evaluation of
Papanasam and Manimuthar watersheds, parts of Western Ghats, Tirunelveli district, Tamil Nadu, India: a GIS approach. Environmental Earth Sciences, 64 (2), 373, 2011.

28. MAGESH N.S., CHANDRASEKAR N. GIS modelbased morphometric evaluation of Tamiraparani subbasin, Tirunelveli district, Tamil Nadu, India. Arabian Journal of Geosciences, 7 (1), 131, 2014.

29. RAO N.K., LATHA S.P., KUMAR A.P., KRISHNA H.M. Morphometric analysis of Gostani river basin in Andhra Pradesh state, India using spatial information technology. International journal of geomatics and geosciences, 1 (2), 179, 2010.

30. MILLER J. R., RITTER D.F., KOCHEL R.C. Morphometric assessment of lithologic controls on drainage basin evolution in the Crawford Upland, South-Central Indiana. American Journal of Science, 290, 569, 1990.

31. DEEPIKA B., AVINASH K., JAYAPPA K.S. Integration of hydrological factors and demarcation of groundwater prospect zones: insights from remote sensing and GIS techniques. Environmental earth sciences, 70 (3), 1319, 2013. 